\title{
EVALUASI KEBERHASILAN LEMBAGA PERKREDITAN DESA (LPD) DALAM MENGGERAKKAN SOSIAL EKONOMI MASYARAKAT PEDESAAN (Studi Pada Lembaga Perkreditan Desa (LPD) Desa Adat Pekutatan)
}

\author{
Oleh: \\ Pera Sundarianingsih \\ Mahasiswa Pasca Sarjana Ilmu Ekonomi Universitas Brawijaya Malang \\ E-mail : pera.sundaria@gmail.com
}

\begin{abstract}
This study aimed to evaluate the success of Village Credit Institutions in moving the social economy of rural communities. The indicator that shows the success Village Credit Institutions observed from three (3) aspects, namely Management, Financial Performance, and the role of socio-economic Village Credit Institutions in mobilizing rural communities. The results of this study can be concluded that Village Credit Institutions Management Pekutatan Village People is good enough. Financial performance Village Credit Institutions Village People Pekutatan terms of aspects Capital, Assets, Earnings, and Liquidity obtained by total final value respectively by 100, it is given a healthy predicate. Traditional Village Pekutatan Village Credit Institutions role in moving the social economy of rural communities is not a financial institution that is solely for the benefit / pure business concept but as a socially minded funding institutions regilius.
\end{abstract}

Keywords: Evaluation, Management, Performance, Social Economy, Village Credit Institutions.

\section{Abstrak}

Penelitian ini bertujuan mengevaluasi keberhasilan Lembaga Perkreditan Desa (LPD) dalam menggerakkan sosial ekonomi masyarakat pedesaan. Indikator yang menunjukkan keberhasilan LPD diamati dari 3 (tiga) aspek, yaitu Pengelolaan, Kinerja Keuangan, dan Peran LPD dalam mengerakkan sosial ekonomi masyarakat pedesaan. Hasil penelitian ini dapat disimpulkan bahwa Pengelolaan LPD Desa Adat Pekutatan sudah cukup baik. Kinerja keuangan LPD Desa Adat Pekutatan ditinjau dari aspek Permodalan,Aktiva Produktif, Earning, dan Likuiditas diperoleh dengan total nilai akhir masing-masing sebesar 100, maka diberi predikat sehat. Peran LPD Desa Adat Pekutatan dalam menggerakkan sosial ekonomi masyarakat pedesaan bukanlah suatu lembaga keuangan yang semata-mata hanya untuk memperoleh keuntungan / konsep bisnis murni melainkan sebagai lembaga pendanaan yang berjiwa sosial regilius.

Kata kunci : Evaluasi, Pengelolaan, Kinerja, Sosial Ekonomi, Lembaga Perkreditan Desa (LPD). 


\section{PENDAHULUAN}

Provinsi Bali yang terkenal dengan adat istiadat yang diatur dalam desa adat tentunya mempunyai hak otonom untuk mengatur kehidupan sosial ekonomi termasuk didalamnya mengatur mengenai pengelolaan kekayaan desa. Dalam hal ini, salah satu kelembagaan keuangan milik masyarakat tingkat desa adalah LPD Sesuai dengan pasal 1 angka 10 Peraturan Daerah Provinsi Bali Nomor 8 tahun 2002 tentang Lembaga Perkreditan Desa (LPD) menyatakan bahwa : LPD adalah Lembaga Perkreditan di Desa Pakraman (desa adat) dalam Wilayah Provinsi Bali.

LPD di Bali mulai berkembang sejak tahun 1985 berdasarkan Surat Keputusan (SK) Gubernur Kepala Daerah Provinsi Bali No. 972 tahun 1984. Berdasarkan Peraturan Daerah (Perda) Provinsi Bali No. 8 Tahun 2002 tentang LPD, bahwa untuk melestarikan dan meningkatkan kemandirian kehidupan desa adat dengan segala aspeknya, dipandang perlu mengadakan usaha-usaha memperkuat keuangan desa sebagai sarana penunjang melalui pendirian suatu badan usaha milik desa berupa LPD yang bergerak dalam usaha simpan pinjam. LPD adalah nama bagi usaha simpan pinjam milik masyarakat desa pakraman (desa adat) yang berada di Provinsi Bali dan merupakan sarana perekonomian masyarakat desa.

Tahap permulaan ditetapkan 8 (delapan) Desa Adat, yaitu Desa Adat Lukluk (Badung), Selumbung (Karangasem), Ekasari (Jembrana), Jullah (Buleleng), Kubu (Bangli), Manukaya (Gianyar), Buahan (Tabanan), dan Penasan (Klungkung). Pada Juli tahun 2012 jumlah LPD di Bali mencapai 1422 buah yang tersebar di 1.482 desa pakraman. Dari jumlah tersebut terdapat 60 desa pakaraman di Bali belum memiliki Lembaga Perkreditan Desa (LPD). (Profil LPD Daerah Bali 2004).

Berdasarkan Keputusan Gubernur Bali Nomor 4 Tahun 2003 tentang Penyetoran dan Penggunaan Keuntungan Bersih LPD ditentukan sebagai berikut: Cadangan Modal 60\%, Dana Pembangunan desa 20\%, Jasa Produksi 10\%, Dana Pembinaan, Pengawasan dan Perlindungan 5\%, dan Dana Sosial 5\%. Manfaat nyata 
dari keberadaan LPDdapat dilihat dari kontribusi sebesar $20 \%$ dari keuntungan bersih tiap tahun untuk dana pembangunan desa, serta $5 \%$ untuk dana sosial berupa uang (fresh money) untuk menunjang pembangunan desa di Bali, sehingga dapat meringankan beban masyarakat dalam hal pembangunan desa maupun iuran dana sosial.

LPD sebagai Lembaga Keuangan Desa bergerak dalam usaha simpan pinjam, dimana produk jasa yang ditawarkan oleh LPD dalam usahanya yaitu melalui tabungan, deposito dan pinjaman dari masyarakat yang kemudian disalurkan dalam bentuk pemberian kredit yang efektif. LPD menyediakan pelayanan jasa keuangan bagi seluruh masyarakat desa termasuk penduduk miskin.

Sedangkan dari segi pelayanan yang dilakukan oleh LPD sesuai dengan kebutuhan nasabah, yaitu prosedur yang sederhana, proses yang singkat, pendekatan personal, serta kedekatan lokasi dengan nasabah menjadi faktor keberhasilan LPD dalam menumbuhkan kepercayaan pada masyarakat desa, sehingga masyarakat mempunyai rasa aman dalam menyimpan dan meminjam uang pada Lembaga Perkreditan Desa (LPD). Kedekatan budaya dan psikologi dengan nasabah, serta karakter bisnis yang luwes merupakan kekuatan dan salah satu faktor yang mempengaruhi kinerja LPDsebagai lembaga keuangan mikro serta dalam bertahan dan berdaya saing terhadap lembaga keuangan yang sejenis.

LPD Desa Adat (Pakraman) pada Kabupaten Jembrana salah satunya, yang diharapkan dapat menggerakkan perekonomian masyarakat pedesaan secara optimal, ditambah pada tahun 2013 hingga saat ini di Kabupaten Jembrana di setiap desa pakraman (desa adat) kini telah berdiri Lembaga Perkreditan Desa (LPD). Jumlah LPD di Kabupaten Jembrana saat ini tercatat sebanyak 64 unit dari 64 desa adat (desa pakraman), hal tersebut menunjukkan bahwa pada masing-masing desa adat (desa pakraman) di Kabupaten Jembrana sudah memiliki Lembaga Perkreditan Desa (LPD).

Peningkatan jumlah unit LPD Kabupaten Jembrana menunjukkan bahwa keberadaan LPD sangat 
dirasakan manfaatnya oleh primer dan data sekunder. Teknik masyarakat desa adat, dalam hal ini pengumpulan data dengan cara LPD Desa Adat Pekutatan Kecamatan menyusun questioner untuk kemudian Pekutatan salah satunya yang dijadikan dasar dalam melakukan merupakan LPD dengan Sisa Hasil wawancara terhadap sampel yang Usaha (SHU) tertinggi di Kabupaten terpilih. Pemilihan sampel LPD Jembrana, dimana pengembangan LPD Desa Adat Pekutatan ditujukan untuk memantapkan dan menumbuhkan swadaya LPD sebagai pusat pelayanan kegiatan perekonomian pedesaan yang berdaya guna dan berhasil guna yang dimiliki oleh desa itu sendiri, untuk keperluan masyarakat dan pembangunan pedesaan sehingga nantinya dapat dijadikan sebagai acuan atau contoh untuk pengembangan pada LPD lainnya di Kabupaten Jembrana.

\section{METODE PENELITIAN}

Penelitian ini dilakukan pada LPD Desa Adat Pekutatan Kecamatan Pekutatan Kabupaten Jembrana Provinsi Bali. Jenis penelitian yang digunakan adalah analisis deskrptif kuantitatif dan kualitatif. Sumber berdasarkan teknik Area Sampling, sedangkan penentuan responden menggunakan dasar teknik Purposive Sampling.

Teknik analisis data dengan melakukan pendeskripsian data-data yang sudah terkumpul melalui questioner, dengan terlebih dahulu melakukan pengolahan data, reduksi data/merangkum data yang nantinya berupa tabel-tabel dan hasil wawancara, menentukan hal-hal pokok pembahasan, menganalisis data dengan menggunakan prosentase dan tahap terakhir tahap penarikan kesimpulan sesuai dengan data-data yang diperoleh. Metode statistik inferensial tidak digunakan karena hasil data yang diperoleh tidak layak untuk diuji sehingga tidak dilakukan uji hipotesis. data yang digunakan adalah Data

Teknik Analisis Penilian Kesehatan LPDDesa Adat Pekutatan terdiri dari :

1) Penilaian Terhadap Permodalan

$$
C A R=\frac{\text { Modal LPD }}{\text { Aktiva Tertimbang Menurut Risiko (ATMR) }} \times 100 \%
$$


2) Penilaian Terhadap Kualitas Aktiva Produktif (KAP)

a) Rasio KAP

$$
\text { Rasio KAP }=\frac{\text { Aktiva Produktif yang Diklasifikasikan }}{\text { Aktiva Produktif }} \times 100 \%
$$

b) Rasio Penyediaan Cadangan Pinjaman Ragu-ragu (CPRR)

$$
\text { Rasio CPRR }=\frac{\text { CPRR yang dibentuk }}{\text { CPRR yang wajib dibentuk }} \times 100 \%
$$

3) Peniliain terhadap Earning / Rentabilitas

a) Return On Assets (ROA)

$$
R O A=\frac{\text { Laba Tahun Buku Berjalan }}{\text { Rata }- \text { rata Asset }} \times 100 \%
$$

b) Rasio Biaya Oprasional Terhadap Pendapatan Oprasional (BOPO)

$$
B O P O=\frac{\text { Biaya Oprasional Th.Buku Berjalan }}{\text { Pendapatan Oprasional Th.Buku Berjalan }} \times 100 \%
$$

4) Likuiditas

a) Rasio alat Likuid

b) Loan To Deposite Ratio (LDR)

\begin{tabular}{|c|c|c|c|}
\hline $\begin{array}{c}\text { Variabel yang } \\
\text { Dinilai }\end{array}$ & & Komponen & Bobot \\
\hline 1. Permodalan & $\begin{array}{l}\text { Kecukupan } \\
\text { Modal (CAR) }\end{array}$ & $\begin{array}{l}\text { Prosentase perbandingan antara Modal } \\
\text { LPD terhadap aktiva tertimbang menurut } \\
\text { risiko (ATMR). }\end{array}$ & $25 \%$ \\
\hline $\begin{array}{l}\text { 2. Kualitas } \\
\text { Aktiva } \\
\text { Produktif }\end{array}$ & $\begin{array}{ll}\text { 1. } & \text { Kualitas Aktiva } \\
\text { Produktif (KAP) } \\
\text { 2. } \\
\text { Cadangan } \\
\text { Pinjaman Ragu- } \\
\text { ragu (CPRR) }\end{array}$ & $\begin{array}{l}\text { 1. Prosentase perbandingan antara aktiva } \\
\text { produktif yang diklasifikasikan terhadap } \\
\text { totalaktiva produktif. } \\
\text { 2. Prosentase perbangingan antara CPRR } \\
\text { yang dibentuk terhadap CPRR yang } \\
\text { wajib dibentuk. }\end{array}$ & $25 \%$ \\
\hline $\begin{array}{l}\text { 3. Earning / } \\
\text { Rentabilitas }\end{array}$ & $\begin{array}{ll}\text { 1. } & \text { ROA } \\
\text { 2. } & \text { BOPO }\end{array}$ & $\begin{array}{l}\text { 1. Prosentase PErbandingan antara laba } \\
\text { terhadap total aktiva. } \\
\text { 2. Prosentase perbandingan antara biaya } \\
\text { terhadap pendapatan. }\end{array}$ & $\begin{array}{l}10 \% \\
10 \%\end{array}$ \\
\hline 4. Likuiditas & $\begin{array}{l}\text { 1. Alat Likuid } \\
\text { 2. LDR }\end{array}$ & $\begin{array}{l}\text { 1. Prosentase perbandingan antara alat } \\
\text { likuid terhadap hutang lancer } \\
\text { 2. Prosentase perbandingan antara hutang } \\
\text { terhadap dana yang diterima }\end{array}$ & $5 \%$ \\
\hline
\end{tabular}

$$
\text { Rasio alat Likuid }=\frac{\text { Kas }+ \text { ABA }}{\text { Hutang Lancar }} \times 100 \%
$$

$$
L D R=\frac{\text { Pinjaman yang Diberikan }}{\text { Dana yang Diterima }+ \text { Modal Inti }} \times 100 \%
$$

Tabel 1. Variabel-variabel yang Dinilai Beserta Bobotnya

Sumber : Peraturan Gubernur Bali Tanggal 7 Maret 2012 Nomor 11 Tahun 2013 


\section{PEMBAHASAN}

LPD Desa Adat Pekutatan dalam upaya mengembangkan usahanya adalah membuat suatu perencanaan (planning) sebagai acuan kerja dalam mencapai suatu tujuan dimasa yang akan datang. Perencanaan yang dibuat oleh LPD, dilakukan setiap 3 (tiga) bulan sebelum tutup tahun buku. Pengurus dan Karyawan berserta Badan Pengawas adalah pihak yang terlibat dalam pembuatan perencanaan acuan kerja LPD dan kemudian disetujui oleh masyarakat desa pakraman (desa adat).

Perencanaan acuan kerja tersebut dibuat atas musyarawah dan mufakat bersama dengan tetap berpedoman pada pengalamanpengalaman pada tahun sebelumnya yaitu mengolah potensi-potensi yang ada di wilayah kerja LPD Desa Adat Pekutatan.

Berdasarkan perencanaan yang telah disetujui, dalam pengopersian usaha LPD Desa Adat Pekutatan menetapkan target sumber dana yang ingin dicapai adalah berasal dari; Sumber dana Modal / Cadangan yang diperoleh dari pembagian laba tiap tahunnya sebesar $60 \%$ dari total laba yang diperoleh, Dana masyarakat yang tediri dari tabunga dan simpanan berjangka, pinjaman yang diterima dan laba tahun berjalan.

Berdasarkan

Struktur

Organisasi Pengurus dan Pengawas Internal LPD Desa Adat Pekutatan, maka baik pengurus, karyawan maupun badan pengawas dapat menjalankan tugas dan fungsinya dengan efektif dan efisien. Sehingga pada masing-masing bidang mengetahui tugas dan fungsi yang harus dijalankan.

Perlu diketahui bahwa, pada struktur organisasi LPD Desa Adat Pekutatan Fungsi / Tugas, dan wewenang tertinggi ada pada paruman desa atau biasa disebut juga dengan rapat desa, yang merupakan bagian teratas dalam suatu organisasi unit kerja LPD yang memberikan kewenangan kepada Bendesa Adat sebagai badan pengawas utama dan dibantu oleh badan pengawas lain yang ditunjuk. Sedangkan seluruh operasional di LPD oleh paruman desa adat diserahkan kepada Ketua LPD sebagai tanggung jawab utama 
dalam pengelolaannya. Seluruh hasil tanggung jawab tersebut, baik dari pengawasan dan pengelolaan dipertanggungjawabkan kembali ke paruman desa adat sebagai bentuk pertanggungjawaban dalam rapat tahunan LPD.

Perencanaan dan pengorganisasian yang baik akan kurang berarti jika tidak diikuti dengan pelaksanaan kerja yang bertanggung jawab. Pelaksanaan kerja harus sejalan dengan rencana kerja yang telah disusun, adapun petunjuk dasar dalam pelaksanaan operasional LPD yaitu: (Laporan Tahunan LPD Desa Adat Pekutatan, 2012)

- Pedoman SOP (Standar Oprasional Penggunaan) Administrasi LPD

- Prinsip kehati-hatian pengelolaan LPD dari BPD Bali.

- Diklat, seminar dan pelatihan tentang LPD, dan

- Petunjuk dari Pembina LPD Kabupaten Jembrana

Dari segi kinerja Sumber Daya Manusia (SDM) LPD Desa Adat Pekutatan, dalam meningkatkan kualitas Sumber Daya Manusia (SDM) pengurus maupun pengelola LPD Desa Adat Pekutatan menerapkan sistim pelatihan serifikasi professional dan melakukan Diklat tentang LPD dan Manajemen. Memotivasi seorang karyawan LPD Desa Adat Pekutatan agar tidak terjadinya kecemburuan sosial antar karyawan maupun pengurus dengan menerapkan sanksi kepada pengurus maupun karyawan, membiasakan diri dengan prinsip "bekerja dulu, baru digaji”, serta pemberian jabatan sesuai dengan masa pengabdian di tempat kerja (LPD).

Memberikan pelayanan maksimal kepada masyarakat agar minat masyarakat menyimpan dana di LPD tinggi dengan memberikan pelayanan seperti cara sistim jemput bola. Sehingga masyarakat yang ingin menempatkan dananya di LPD tidak perlu datang kekantor untuk mengurus semua persyaratan yang dibutuhkan. Permasalahan yang sering dihadapi dalam penembangan usaha LPD adalah sempitnya lingkup kerja LPD yaitu hanya 1 desa sehingga mengakibatkan permasalahan seperti terjadinya over likuid (kelebihan dana).

Strategi atau terobosan yang dilakukan dalam mengatasi hal 
tersebut adalah melakukan ekspansif kredit, yaitu melakukan penurunan bunga kredit agar minat masyarakat terhadap kredit meningkat. Pada produk jasa tabungan dan deposito juga dilakukan penurunan bunga, sehingga minat masyarakat menyimpan dananya di LPD dapat menurun sehingga over liquid yang terjadi dapat teratasi.

Pengawasan LPD Desa adat Pekutatan berlandaskan hukum diantaranya: (rencana kerja dan rencana anggaran pendapatan dan belanja LPD Desa Adat Pekutatan, 2012)

1. Surat Keputusan Gubernur No. 58 th $1991 \operatorname{tgl} 5$ Februari 1991

2. Peraturan Daerah Tk. I Bali No. 8 th 2002 tentang Lembaga Pekreditan Desa

3. Surat Keputusan Bupati Jembrana No. 73 th. 1991 tgl 19 Maret tentang Pengangkatan LPD se-Kabupaten Jembrana.

Tolak ukur sebagai acuan untuk menilai pelaksanaan atas anggaran LPD yang telah ditetapkan dan disahkan agar dapat digunakan sebagai tolok ukur atas penyimpangan anggaran diantaranya : $1-5 \%$ diberi kategori sangat memuaskan, 8-10\% diberi kategori cukup memuaskan, sedangkan $11-15 \%$ diberi kategori kurang memuaskan : Bila terjadi penyimpangan $15 \%$ diatas anggaran tahunan maka perlu diadakan peninjauan kembali atas anggaran tahunan yang telah ditetapkan / disahkan (rencana kerja dan rencana anggaran pendapatan dan belanja LPD Desa Adat Pekutatan, 2012).

Rasio kecukupan modal yang ditetapkan untuk LPD adalah sebesar $12 \%$ berguna sebagai dasar pengembangan usaha LPD yang sehat sehingga dapat menampung kerugian serta berguna untuk melakukan pemantauan terhadap kondisi permodalan LPD yang sehat. Rasio modal (CAR) yang dicapai pada tahun 2011 sebesar 26\%, sedangkan pada tahun 2012 sebesar $27 \%$. Semakin besar rasio dari $12 \%$, maka akan semakin baik. Apabila rasio tersebut diatas $12 \%$, artinya rasio modal (CAR) berada dalam predikat sehat. Kemampuan dalam menjaga kelangsungan usaha LPD, maka rasio Kualitas Aktiva Produktif (KAP) yang harus dicapai adalah lebih besar dari 20\% maka dapat dikategorikan 
sehat. Rasio KAP yang diperoleh adalah tahun 2011 sebesar 1,67\% dan tahun 2012 sebesar 2,61\%.

Hasil perhitungan ROA tahun 2011 dan 2012 berada diatas 2,5\% sehingga memperoleh predikat sehat dengan total nilai yang diakui masingmasing adalah sebesar 100. Hal tersebut menunjukkan kinerja ROA LPD Desa Adat Pekutatan masih baik, dimana terlihat dari peningkatan laba bersih yang dihasilkan dari total asset yang dimiliki pada tahun 2011 dan 2012 sehingga LPD Desa Adat Pekutatan mampu menggunakan dan mengelola asset yang dimiliki untuk menghasilkan laba secara efektif. Rasio BOPO ditahun 2011 dan 2012 masih tetap berada dibawah rasio BOPO yang ditentukan yaitu $75 \%$ sehingga berada dalam kategori sehat dengan total nilai yang diakui masingmasing sebesar 100. Perhitungan BOPO ini mempunyai arti bahwa LPD Desa Adat Pekutatan mampu menghasilkan pendapatan oprasional dengan menggunakan assets yang dimilikinya dan biaya oprasional yang dikeluarkan secara efektif.

Rasio alat likuid yang harus dicapai oleh LPD untuk memperoleh predikat sehat adalah di atas $5 \%$. Perolehan rasio likuiditas tahun 2011 sebesar $41,70 \%$ dan tahun 2012 sebesar 39,96 sehingga rasio alat likuid yang dicapai oleh LPD Desa Adat Pekutatan mendapatkan predikat sehat dengan total nilai yang diakui masing-masing sebesar 100. Hal Ini berarti bahwa LPD Desa Adat Pekutatan agar mampu membayar hutang yang segera harus dipenuhi dengan menggunakan alat likuid yang dimilikinya. LDR yang harus dipenuhi oleh LPD untuk memperoleh predikat sehat adalah di bawah 94,75\%. Besarnya LDR yang diperoleh tahun 2011 sebesar 67,88\%, sedangkan tahun 2012 sebesar 69,93\%, maka diperoleh predikat sehat. LPD Desa Adat Pekutatan mampu menjamin kewajibankewajiban lancarnya dengan alat-alat likuid yang dimiliki, serta mampu menutup potensi kerugian yang mungkin timbul dari penanaman dana LPD dalam bentuk kredit atau pinjaman yang diberikan dengan menggunakan dana yang diterima. Maka semakin tinggi rasio LDR semakin tinggi pula tingkat likuiditasnya. Berdasarkan uraian- 
uraian tersebut, maka dapat Periode 31 Desember 2011 dan 2012 disimpulkan hasil akhir penilaian disajikan pada tabel berikut.

kesehatan LPD Desa Adat Pekutatan

Tabel 2. Kompilasi Hasil Penilaian KesehatanLembaga Perkredita Desa (LPD) Desa Adat Pekutatan Periode 31 Desember 2011

\begin{tabular}{|c|l|c|c|c|c|}
\hline \multirow{2}{*}{ No. } & \multicolumn{1}{|c|}{$\begin{array}{c}\text { Faktor / Komponen CAMEL } \\
(\mathbf{1})\end{array}$} & $\begin{array}{c}\text { Rasio } \\
(\mathbf{2})\end{array}$ & $\begin{array}{c}\text { Nilai } \\
\mathbf{( 3 )}\end{array}$ & $\begin{array}{c}\text { Bobot } \\
\mathbf{( 4 )}\end{array}$ & $\begin{array}{c}\text { Nilai } \\
\text { Kesehatan } \\
(\mathbf{5})=(\mathbf{4 x 3})\end{array}$ \\
\hline 1 & Permodalan (CAR) & 26 & 225 & $25 \%$ & 56.36 \\
\hline \multirow{2}{*}{2} & Kualitas Aktiva Produktif (KAP) & 1.67 & 122.17 & $25 \%$ & 30.54 \\
\cline { 2 - 6 } & CPRR & 170.85 & 170.85 & $10 \%$ & 17.09 \\
\hline \multirow{2}{*}{3} & Return On Asset (ROA) & 6 & 241 & $10 \%$ & 24.10 \\
\cline { 2 - 6 } & BOPO & 4.10 & 383.59 & $10 \%$ & 38.36 \\
\hline \multirow{2}{*}{4} & Alat Likuid & 41.70 & 834 & $5 \%$ & 41.70 \\
\cline { 2 - 6 } & Loan To Deposite Ratio (LDR) & 67.88 & 188.47 & $5 \%$ & 9.42 \\
\hline \multicolumn{5}{|c|}{ Total Nilai CAEL } \\
\hline \multicolumn{6}{|c|}{ Total Nilai Kesehatan } \\
\hline \multicolumn{6}{|c|}{ Kriteria } \\
\hline
\end{tabular}

Tabel 3. Kompilasi Hasil Penilaian KesehatanLembaga Perkredita Desa (LPD) Desa Adat PekutatanPeriode 31 Desember 2012

\begin{tabular}{|c|l|c|c|c|c|}
\hline \multirow{2}{*}{ No. } & \multicolumn{1}{|c|}{$\begin{array}{c}\text { Faktor / Komponen CAMEL } \\
(\mathbf{1})\end{array}$} & $\begin{array}{c}\text { Rasio } \\
(\mathbf{2})\end{array}$ & $\begin{array}{c}\text { Nilai } \\
(\mathbf{3})\end{array}$ & $\begin{array}{c}\text { Bobot } \\
(\mathbf{4})\end{array}$ & $\begin{array}{c}\text { Nilai } \\
\text { Kesehatan } \\
(\mathbf{5})=(\mathbf{4 x 3})\end{array}$ \\
\hline 1 & Permodalan (CAR) & 27 & 231 & $25 \%$ & 57.65 \\
\hline \multirow{2}{*}{2} & Kualitas Aktiva Produktif (KAP) & 2.61 & 115.92 & $25 \%$ & 28.98 \\
\cline { 2 - 6 } & CPRR & 149.43 & 149.43 & $10 \%$ & 14.94 \\
\hline \multirow{2}{*}{3} & Return On Asset (ROA) & 6 & 235 & $10 \%$ & 23.50 \\
\cline { 2 - 6 } & BOPO & 3.89 & 384.43 & $10 \%$ & 38.44 \\
\hline \multirow{2}{*}{4} & Alat Likuid & 39.96 & 799 & $5 \%$ & 39.96 \\
\cline { 2 - 6 } & Loan To Deposite Ratio (LDR) & 69.93 & 180.27 & $5 \%$ & 9.01 \\
\hline \multicolumn{5}{|c|}{ Total Nilai CAEL } \\
\hline \multicolumn{5}{|c|}{ Total Nilai Kesehatan } & $\mathbf{2 1 2 . 4 9}$ \\
\hline \multicolumn{5}{|c|}{ Kriteria } \\
\hline
\end{tabular}

Berdasarkan Tabel 2 dan 32011 dan 2012 yaitu total nilai akhir diperoleh nilai akhir tingkat kesehatan untuk kedua tahun tersebut masingLPDDesa Adat Pekutatan Kecamatan Pekutatan Kabupaten Jembrana tahun masing sebesar 100. Total akhir yang diperoleh LPD Desa Adat Pekutatan 
selama dua periode diberi predikat sehat karena rata-rata nilai kredit berada pada nilai maksimum yaitu 100 , dengan permodalan yang sehat diharapkan LPDDesa Adat Pekutatan dapat melakukan kegiatan operasionalnya dengan baik, sehingga semakin baik LPD dalam melakukan kegiatan operasionalnya maka semakin tinggi pula laba yang diperoleh LPD, dengan adanya hal terebut tentu akan berpengaruh pula terhadap kontribusi LPD untuk desa. Sedangkan bagi masyarakat dengan permodalan yang sehat maka LPDDesa Adat Pekutatan akan mendapat kepercayaan dari masyarakat untuk menyimpan dananya berupa tabunga dan deposito pada LPD Desa Adat Pekutatan.

LPD dalam hal aktivitas sosial dan keagamaan terlihat pada pembagian keuntungan bersih tiap tahunnya dimana 20\% adalah Dana Pembangunan Desa, dan 5\% adalah Dana Sosial. Berikut tabel perolehan laba LPD beserta pos peruntukkannya.

Tabel 4. menunjukkan bahwa pertumbuhan jumlah laba mengalami penurunan, hal ini disebabkan pada tahun 2008 merupakan tahap-tahap perkembangan LPD Desa Adat Pekutatan dalam mengembangkan usahanya kearah sosial keagamaan, sehingga pertumbuhan tertinggi terjadi pada tahun 2008. Meskipun dari segi pertumbuhan mengalami penurunan namun dari segi jumlah yang diperoleh justru mengalami peningkatan.

Wilayah kerja LPD hanya pada 1 (satu) desa adat tidak menutup kemungkinan bahwa LPD tidak akan dapat berkembang, karena sempitnya cakupan wilayah kerja LPD maka LPD yang ada di desa dapat lebih fokus dalam pengembangan wilayah kerja LPD, seperti dalam hal pembagian keuntungan LPD 20\% untuk dana pembangunan desa, dimana biasanya masyarakat dikenakan biaya iuran dalam hal pembangunan pura, karena adanya pembagian keuntungan LPD maka beban masyarakat dalam hal biaya iuran tidak terbebani, perbaikan ifrastruktur desa seperti perbaikan irigasi, dimudahkannya dalam hal kegiatan-kegiatan ritual keagamaan baik nyepi maupun hari raya besar lainnya serta pemberian bantuan dana 
untuk sekolah-sekolah swasta. Dana $20 \%$ bukanlah LPD langsung yang mengelola melainkan LPD hanya menyerahkannya dalam bentuk uang tunai kepada pengurus desa Adat kemudian dimasukkan dalam kas desa Adat, sehingga kebijakan pengelolaan serta penggunaan dana tersebut diatur oleh pengurus desa Adat (Desa Pakraman).

Pembagian Laba 5\% digunakan untuk dana sosial. LPD Desa Adat Pekutatan menyalurkan pembagian keuntungannya kepada masyarakat berupa kegiatan sosial seperti pemberian bantuan berupa uang tunai maupun bantuan fisik lainnya terhadap yayasan-yayasan yang khususnya adalah merupakan yayasan hindu, bantuan dana terhadap seka truna (karang taruna) dalam hal pembuatan ogoh-ogoh, serta kegiatan sosial seperti kematian pemberian bantuan berupa uang tunai, maupun pemberian bahan-bahan sembako dan memberi bantuan bahan pakaian untuk pemangku (orang yang disucikan dalam agama hindu). Maka dapat disimpulkan, bahwa LPD bukanlah lembaga keuangan yang semata-mata hanya untuk menyimpan dan menyalurkan dana kepada masyarakat tetapi juga sebagai lembaga keuangan yang kegiatannya operasionalnya murni sebagai lembaga keuangan yang berjiwa sosial dan religius.

Tabel 4. Pembagian Laba LPD Desa Adat Pekutatan

\begin{tabular}{|c|c|c|c|c|}
\hline \multirow[b]{2}{*}{ Tahun } & \multirow[b]{2}{*}{$\begin{array}{c}\text { Jumlah Laba } \\
\qquad(100 \%)\end{array}$} & \multirow[b]{2}{*}{$\begin{array}{c}\text { Pertumbuhan } \\
\text { Jumlah Laba } \\
\text { (\%) }\end{array}$} & \multicolumn{2}{|c|}{ Pos Peruntukan } \\
\hline & & & $\begin{array}{c}\text { Dana } \\
\text { Pembangunan } \\
(20 \%)\end{array}$ & $\begin{array}{c}\text { Dana Sosial } \\
(5 \%)\end{array}$ \\
\hline 2008 & $\mathrm{Rp} \quad 222,630,226$ & - & Rp 44,526,045 & Rp 11,131,511 \\
\hline 2009 & $\begin{array}{ll}\mathrm{Rp} & 412,961,781 \\
\end{array}$ & $85 \%$ & Rp $82,592,356$ & Rp $20,648,089$ \\
\hline 2010 & $\begin{array}{ll}\mathrm{Rp} & 471,006,716\end{array}$ & $14 \%$ & $\operatorname{Rp} 94,201,343$ & Rp 23,550,335 \\
\hline 2011 & Rp $\quad 561,092,992$ & $19 \%$ & Rp 12,218,598 & Rp 28,054,649 \\
\hline 2012 & $\begin{array}{ll}\mathrm{Rp} & 652,061,193 \\
\end{array}$ & $16 \%$ & Rp 130,412,238 & Rp 32,603,059 \\
\hline
\end{tabular}

Hal tersebut menunjukkan pada saat pembagian laba seperti bahwa kegiatan usaha LPD tidak yang telah diatur dengan Peraturan menutup diri dari masyarakat yang Gubernur Nomer 4 Tahun 2003 bukan beragama hindu, hanya saja Tentang Penyetoran dan Penggunaan 
Keuntungan Bersih LPD (20\% dana pembangunan dan $5 \%$ dana sosial) tidak diperuntukkan untuk masyarakat luas, mengingat bahwa kemelikan LPD adalah Komunitas Adat Hindu (Kesatuan Masyarakat Hindu) dan wilayah kegiatannya usahanya hanya sebatas 1 (satu) desa ada. Sehingga peruntukanperuntukannya cenderung pada kegiatan-kegiatan sosial-keagamaan hindu.

$\begin{array}{rrr}\text { Selain } & \text { kegiatan } & \text { sosial- } \\ \text { keagamaan hindu, laba yang }\end{array}$
diperoleh LPD juga diberikan kepada sekolah-sekolah yayasan (nonhindu), sehingga tidak menutup kemungkinan bahwa laba yang diperoleh LPD hanya diperuntukkan kepada kegiatan-kegiatan sosialkeagaman hindu. Keputusan dan kebijakan pengelolaan laba yang diperoleh LPD dikembalikan lagi pada paruman desa yang merupakan kedudukan tertinggi dalam struktur organisasi LPD.

Paruman Desa merupakan suatu perkumpulan masyarakat, tokoh-tokoh masyarakat beserta badan pengawas, bendesa adat desa pakraman, dan pengurus LPD dalam suatu rapat yang disebut rapat desa (paruman desa). Sehingga keputusan dan kebijakan pengelolaan laba yang diperoleh LPD ada pada keputusan hasil rapat desa (paruman desa).

Berdasarkan uraian-uraian tersebut menunjukkan bahwa, LPD bukanlah lembaga keuangan yang semata-mata bidang usahanya untuk memperoleh keuntungan melalui menyimpan dan menyalurkan dana kepada masyarakat tetapi juga sebagai lembaga keuangan yang kegiatannya operasionalnya murni sebagai lembaga keuangan yang berjiwa sosial dan religius.

Besaran modal yang diterima berupa kredit yang disalurkan oleh LPD kepada masyarakat sangat berpengaruh terhadap perekonomian dan kemajuan usaha masyarakat desa. Hal tersebut dikarenakan jika bantuan kredit dianggap terlalu kecil, maka tambahan modal tidak dapat secara nyata bermanfaat untuk kemajuan usaha karena nantinya akan cenderung dimanfaatkan untuk pemenuhan kebutuhan sehari-hari. Hasil wawancara terhadap kesesuaian kredit menunjukkan 13 $(48,14 \%)$ responden menyatakan 
bahwa kredit yang diterima jauh lebih kecil dari yang dibutuhkan dan $11(40,47 \%)$ Responden menyatakan bahwa kredit yang diterima sudah sesuai dengan kebutuhan, namun demikian masih terdapat $3(11,11 \%)$ responden yang menyatakan bahwa kredit yang diterimnya lebih besar dari kebutuhan kerja mereka.

Responden yang menyatakan bahwa kredit yang diterima jauh lebih kecil dari yang dibutuhkan adalah responden dengan penerimaan kredit dibawah 5 juta rupiah dan diatas 16 juta rupiah. Sedangkan yang menyatakan penerimaan kredit sesuai dengan kebutuhan adalah responden dengan penerimaan kredit diatas 5 juta sampai dengan 15 juta. Dari uraian tersebut dapat disimpulkan bahwa tidak semua kredit yang diterima oleh responden adalah mereka yang memiliki modal besar sehingga hasil yang diperoleh dari responden beragam.

Penyaluran kredit oleh LPDDesa Adat Pekutatan memiliki potensi cukup besar dalam menggerakkan kegiatan ekonomi masyarakat desa. Mengingat bahwa hasil wawancara terhadap responden mengenai LPD Desa Adat Pekutatan bahwa $100 \%$ responden mengatakan syarat untuk mengajukan kredit adalah sangat mudah dipenuhi dan $89 \%$ responden mengatakan tahap dalam pengajuan dan realisasi kredit dirasa sangat mudah, cepat dan tidak membutuhkan waktu lama, sehingga banyak responden mengaku pelayanan LPD Desa Adat Pekutatan terhadap masyarakat kecil sangat memuaskan, hal itu terlihat dari nasabah LPD Desa Adat Pekutatan yang tidak hanya dari golongan menengah keatas tetapi juga golongan menegah kebawah. Oleh sebab itu, LPD Desa Adat Pekutatan tetap dijadikan prioritas utama oleh masyarakat khususnya jika ada kebutuhan dana yang mendesak.

Pemanfaatan kredit yang diterima untuk kebutuhan usaha berkisar antara 90\% - 100\%. Hal ini mengartikan bahwa dana yang diterima kepada nasabah kredit benar-benar dimanfaatkan sebagai modal kerja. Meskipun demikian terdapat perbedaan pada hasil wawancara lainnya, dimana hanya 3 (11\%) dari responden mengalami perubahan pendapatan setelah 
menerima tambahan modal kerja. Sedangkan sisanya $24 \quad(89 \%)$ responden tidak mengalami perubahan. Namun yang patut dicermati adalah responden yang mengatakan bahwa tidak ada perubahan dalam usahanya adalah responden yang kegiatan usahanya hanya digunakan untuk pemenuhan kebutuhan sehari-hari, sehingga tidak ada pemisahan antara keuangan keluarga dengan keuangan usaha. Sedangkan disisi lain beberapa responden memilih memanfaatkan sisa kredit yang diterima untuk kegiatan penunjang lainnya seperti perbaikan rumah, perbaikan tempat usaha dan biaya pendidikan anak.

Kelancaran pembayaran angsuran dan tingkat bunga merupakan prasyarat akan keberhasilan LPD Desa Adat Pekutatan dalam menyalurkan dana ke masyarakat berupa kredit. Hasil wawancara yang diperoleh mengenai keterlambatan membayar angsuran adalah hanya $5(18,52 \%)$ responden yang mengatakan pernah terlambat membayar angsuran, sisanya 22 $(81,48 \%)$ tidak pernah. Hal ini diperkuat dengan hasil wawancara yg menunjukkan bahwa responden yang tidak pernah terlambah adalah responden yang ingin segera melunasi angsurannya, sehingga jika nanti angsuran telah lunas maka responden akan menambah kredit lagi. Adanya pernyataan tersebut menunjukkan masyarakat lebih memilih lembaga keuangan sepeti LPD Desa Adat Pekutatan untuk kebutuhan usaha maupun kebutuhan konsumtif lainnya.

\section{KESIMPULAN}

Perencanaan yang disusun telah memenuhi standar POAC pada umumnya meski masih sangat sederhana. Dalam pelaksanaan maupun sampai pada pengawasan sudah sesuai dengan standar yang disepakati atau standar perencanaan yang disusun. Sehingga dalam operasional kerjanya LPD sudah memiliki acuan dalam merealisasikan tujuan yang disepakati.

Berdasarkan hasil perhitungan dan analisis kinerja keuangan LPD Desa Adat Pekutatan pada periode 2011 dan 2012 diperoleh hasil total nilai akhir 
sebesar 100, dengan ketentuan total nilai akhir maksimum adalah 100 maka diberi predikat sehat. Permodalan yang sehat dapat berpengaruh pada kegiatan operasional yang baik, dan berdampak pada tingginya kepercayaan masyarakat untuk menyimpan dananya pada LPD Desa Adat Pekutatan, maka hal tersebut juga akan berpengaruh terhadap besaran kontribusi laba/keuntungan yang diperoleh LPD terhadap desa.

Berdasarkan pernyataan dan data-data yang diperoleh diketahui bahwa LPD bukanlah lembaga keuangan yang semata-mata hanya untuk menyimpan dan menyalurkan dana kepada masyarakat tetapi juga sebagai lembaga keuangan yang kegiatannya operasionalnya murni sebagai lembaga keuangan yang berjiwa sosial dan religius.

Kredit yang disalurkan 90$100 \%$ dimanfaatkan sebagai modal kerja. Hasil lain menunjukkan tidak terjadi perubahan produksi setelah menerima tambahan modal kerja, hal tersebut dikarenakan responden yang kegiatan usahanya hanya digunakan untuk pemenuhan kebutuhan sehari- hari, sehingga tidak ada pemisahan antara uang keluarga dengan uang usaha.

\section{DAFTAR PUSTAKA}

Boediono, 1992, Ekonomi Makro. Seri Sinopsisi Pengantar Ilmu Ekonomi No. 2. Edisi 4, BPFE, Yogyakarta.

Burhan Bungin, 2003, Analisis Data Penelitian Kualitatif; PT. Raja Grafindo Persada, Jakarta.

I Gusti Wayan Murjanayasa, 2008, Lembaga Perkreditan Desa (LPD) Dalam Membangun Ekonomi Rakyat di Kecamatan Denpasar Barat.

Koentjaraningrat, 1990, Pengantar Ilmu Antropologi, Rineka Cipta, Jakarta.

Lincolin Arsyad, 1999, Ekonomi Pembangunan, Sekolah Tinggi Ilmu Ekonomi YKPN, Yogyakarta.

Mubyarto, 2003, Membangun Sistem Ekonomi, BPFE, Yogyakarta.

Nuraini, Ida SE., M.Si, 2009, Pengantar Ekonomi Mikro, UMM Press, Malang.

Peraturan Gubernur Bali Tanggal 7 Maret 2012 No.11 Tahun 2013 Tentang Lembaga Perkreditan Desa.

Pemerintah Tingkat I Bali, 2002. Peraturan Daerah no.8 tahun 2002 tentang Lembaga Perkreditan Desa (LPD) Bali -----------, 2003. Peraturan Daerah No.12 Tahun 2003 tentang Prinsip Kehati-Hatian dalam 
Mengelola Lembaga

Perkreditan Desa (LPD) Bali.

Peraturan Daerah Provinsi Bali No.3

Tahun 2001, Tentang Desa

Pakraman.

Peraturan Daerah Provinsi Bali No.8

Tahun 2002, Tentang Lembaga

Perkreditan Desa (LPD).

Peraturan Gubernur Provinsi Bali

No.4 Tahun 2003, Tentang

Penyetoran dan Penggunaan

Keuntungan Bersih Lembaga

Perkreditan Desa (LPD).

Peraturan Daerah Provinsi Bali No.3

Tahun 2007, Tentang Lembaga

Perkreditan Desa (LPD).

Peraturan Gubernur Provinsi Bali 7

Maret No.11 Tahun 2013,

Tentang Penilaian Lembaga

Perkreditan Desa (LPD).

Putra, Ida Bagus Wyasa 2011,

Landasan Teoretik Pengaturan

Lembaga Perkreditan Desa

(LPD) Sebagai Lembaga

Keuangan Komunitas

Masyarakat Hukum Adat di

Bali ; Udayana University

Press, Denpasar.

Racmat Hendayana dan Sjahrul

Bustaman, 2008, Fenomena

Lembaga Keuangan Mikro

Dalam Perspektif

Pembangunan Ekonomi

Pedesaan.
Suartana, I Wayan, 2009, Arsitektur

Pengelolaan Risiko pada LPD

(Lembaga Perkreditan Desa).

Udayana University Press,

Denpasar

Sugiyono, 2007, Metode Penelitian Bisnis, CV. Alfabeta,

Bandung.

Taswan, Dr. (Cand.) SE.,M.Si, 2010, Manajemen Perbankan

Konsep, Teknik dan Aplikasi, UPP STIM YKPN, Yogyakarata

Wijono, 2005, "Pemberdayaan Lembaga Keuangan Mikro Sebagai Salah Satu Pilar Sistem Keuangan Nasional : Upaya Konkrit Memutus Mata Rantai Kemiskinan", Kajian Ekonomi dan Keuangan. Edisi Khusus November 2005.

Winardi, 1992, Manajemen Perilaku Organisasi. PT Citra Aditya Bakti, Bandung.

Wirutomo, Paulus, 2012, Sistem Sosial Indonesia, Jakarta : Universitas Indonesia.

http://jembranakab.go.id//Profil-

BPMPD-Kabupaten-Jembrana2012.html(diakses pada tanggal 01 oktober 2013)

http://jembranakab.go.id//ProfilKabupaten-Jembrana-

2012.html (diakses pada tanggal 01 oktober 2013) 